\title{
IJELTAL
}

\section{Project-based Learning Implementation to Cultivate Preservice English Teachers' 21st Century Skills}

\author{
Evi Puspitasari \\ Universitas Muhammadiyah Yogyakarta \\ e-mail:evipuspitasari@fpb.umy.ac.id
}

\begin{abstract}
:
The contribution of Project-based Learning $(P b L)$ to 21st century learning skill development has been widely discussed by experts. This present qualitative research aims at exploring how PbL is applied in Lantern School of English Education (LSEE), an undergraduate program in Indonesia that produces an English teacher. In further, this research also looked at how the implementation enhanced the students' 21st century learning skills comprising creativity, critical thinking, collaboration, and communication. Considering those objectives, this research stood under qualitative approach and specifically employed case study design in order to investigate a single case which was project-based learning implementation in a particular context. The data were collected from interview, observation, and relevant documents which in this case, reflective essay, syllabus and students' final projects. Observation and syllabus were used to investigate the implementation of PbL in LSEE, interviews and was to gather information about how the implementation cultivated students 21st century skills, while students' works and reflective essay were to triangulate information from the other data collection techniques. After gaining the data, all were analysed using coding process to obtain the embedded themes as findings. The findings showed that the institution implemented PbL through the assessment, classroom activities, teacher roles, and student roles. Based on the students' viewpoints, project-based assessment, group classroom activities, teachers being a facilitator, and students' centeredness were successfully trained their ability on creativity, critical thinking, collaboration, and communication. Conclusion and recommendation are also presented after the findings were discussed.
\end{abstract}

Keywords: 21st century skills, PbL, pre-service teachers, project-based learning 


\section{Introduction}

In the era of 21st century, cognitive abilities are not considered as an absolute item that defines students' success. That is supported by Wongdaeng \& Hajihama (2018) who mentioned that students in this era must be aware of the future changing and equip themselves with skills required for more challenging life in the future. To survive in this competitive period, students need to think critically so that they can find initiatives and thoughtful solution when problems come across. Since in this era, networking becomes a key of success, students then need to have good communication skill an able to work collaboratively. In order to keep up with rapid changes, they are required to be creative and innovative. Those aspects are called ${ }_{4} \mathrm{Cs}$ which stand for critical thinking and problem solving, communication, collaboration, and creativity and innovation skills. In line with that, Saxena (2014) said the aforementioned qualities equip the students to be successful on career, education, and citizenship.

Seeing the urgency of ${ }_{4} \mathrm{Cs}$ to students' achievement, experts in education suggested Project-based Learning ( $\mathrm{PbL}$ ) as a promising instructional design to enhance the skills. Cocco (2016) conveyed that PbL is a method of teaching that stands under a constructivist approach which focuses on engaging students with series of research-oriented activities that involve their collaborative actions to achieve their goal. Wurdinger, Haar, Hugg, and Bezon (2007) said, by doing the activities and involving themselves in social interaction, students will get meaningful hands-on experiences that strengthen their individual capabilities including critical thinking, communication, collaboration, and creativity skills.

The popularity of PbL to develop students' ${ }_{4} \mathrm{Cs}$ as a part of 21st skills, is also proven by previous empirical studies conducted in several settings such as Thailand (Wongdaeng \& Hajihama, 2018), Turkey (Bedir, 2019), Indonesia (Mali, 2016), the USA (Allison, 2018), India (Talat \& Chaudhry, 2014), and United Arab Emirates (Bani-Hamad \& Abdullah, 2019). The previous studies involved different groups of participants such as EFL (English as a Foreign Language) students (Mali, 2016; Wongdaeng \& Hajihama, 2018), international staff members (Allison, 2018), in-service teachers (Talat \& Chaudhry, 2014), pre-service teachers (Bedir, 2019) and secondary students (Bani-Hamad \& Abdullah, 2019). In terms of types of ${ }_{4} \mathrm{Cs}$ that are improved through the implementation of $\mathrm{PbL}$, Wongdaeng and Hajihama (2018) focused on aspects of collaboration and communication, Talat and Chaudry (2014) put the center on creativity and competitiveness, while Mali (2016) was interested in digging out the benefits of the approach to students' collaboration and creativity skills. From the extensive areas of $\mathrm{PbL}$ and ${ }_{4} \mathrm{Cs}$ skills discussed in those previous studies that help people understand those variables from using various angles, none of them zoomed in the lens on EFL pre-service teachers who might get inspired from the on-going PbL implementation and intended to apply the approach in their own classes when they become in-service English teachers.

According to long-term observation that the researcher did, Lantern School of English Education (LSEE), an English teacher training center that provides an undergraduate program for English pre-service teachers in Indonesia implemented $\mathrm{PbL}$ in most of offered classes. Commonly, the classes asked the students to collaborate with other students to do a final project that they should be submitted in the end of the semester. What they did in weekly meetings is to scaffold the students to finish the project. The implementation is one 
of supports that LSEE gives to enhance students' capabilities and prepare them to be a qualified English teacher. In addition, the pre-service teachers need to develop their qualities so that they can keep up the exponent changes of education world. Significant qualities that they need to sharpen to complement their pedagogical competence and content knowledge which belong to characteristics that English teachers should have (Murtiningsih, 2017) are critical thinking, collaboration, communication, and creativity ( $4 \mathrm{Cs})$. In the curriculum of LSEE, enhancement of the skills actually has been decided as one of the learning objectives that the pre-service teachers must achieve. They are not literally known as ${ }_{4} \mathrm{Cs}$ but familiarly mentioned as soft skills. In regard to that fact, this research aims to explore how PbL implementation in LSEE supports the preservice English teachers (PETs)' 21st century skills especially their ${ }_{4} \mathrm{Cs}$. The research questions were formulated into "How was Project-based learning implemented in LSEE?" and "How does the implementation develop PETs' 21st century skills?"

\section{Literature Review}

Some experts gave further definition of PbL by depicting the characteristics and explaining what students generally do in the conceptual plan. Krajcik and Blumenfeld (2006) saw PbL as a variation of other constructivist learning model such as inquiry, problem-based, and collaborative learning. From that notion, it is noticeable that PbL has characteristics of constructivist approach comprising prior knowledge activation, exploration, and studentcenteredness (Tsybulsky, Gatenio-Kalush, Ganem, \& Grobgeld, 2020). Tsybulsky et al also added that to lead the students doing the process of learning, a question or a problem is given. In parallel, Kokotsaki, Menzies, and Wiggins (2016) elaborated a sequence of doing the project which starts from sharing and discussion to recall existing knowledge of a certain topic to invite students' curiosity. It is continued with exploration to respond the problem and the answer by going through hands-on experiences. Seeing that most of activities are done by students either individually or collaboratively, one more constructivist type is found in PbL which is students as the active doer in learning (Tracey \& Morrow, 2012). In detailed information, Jalinus, Nabawi and Mardin (2017) said that activities of PbL commenced from formulating the intended learning outcome and continued with understanding the concept of teaching material, training needed skills, designing the project theme, making the project proposal, and executing the project works. At the end of the process, the students should present the project report.

Advancing students' 21st century skills is one of obvious benefits that PbL offers (Allison, 2018; Bani-Hamad \& Abdullah, 2019; Bedir, 2019; Mali, 2016; Talat \& Chaudhry, 2014; Wongdaeng \& Hajihama, 2018). In general, the skills have three main subskills namely learning skills, literacy skills, and life skills. Among those skills, the most mentioned and discussed skills in an educational context is learning skills which consist of critical thinking, creativity, collaboration, and communication or are familiarly known as $4 \mathrm{Cs}$.

The first $C$ of 21 st century learning skills is creativity or creative thinking skill. This ability enables students to view ideas in a different angle to result in innovation. That notion is in line with some different experts. Nakano and Wechsler (2018) stated that creativity could enhance students' quality in both personal and professional domain. Another si gnificance is addressed by Krentzman (2013) who specifically mentioned that the skill gives a positive influence on students' attitude to humanity which is also in parallel with Pfeiffer \& Wechsler 
(2013).In accordance, Nakano and Wechsler (2018) viewed creativity can develop students' social and individual excellence. All those aforementioned points could be gained through the creative process starting from preparation continued with incubation for an idea, illumination that is being ended with verification (Treffinger \& Isaksen, 2005). For creative individuals, Almeida and Weschler (Almeida \& Wechsler, 2015) characterized them as ones who are curious, tolerant toward diverse ideas, autonomous, confident, persistent, and highly motivated. Adding Almeida and Weschler's list, Isaksen, Dorval, and Treffinger (2011) considered that generally, creativity was shown from people with ability to address problems in transformative ways and to think out of the box.

The second item of ${ }_{4} \mathrm{Cs}$ as part of 21 st century learning is critical thinking. According to the thinking hierarchy of Bloom's Taxonomy (Anderson \& Krathwohl., 2001), critical thinking is considered as high order of thinking. Students who have this skill usually do not only stop in knowledge, comprehension, and application but they pass the level of analysis, synthesis, and evaluation. The more students train those skills, the higher critical thinking skill the students have (Nevid \& McClelland, 2013). In a brief statement, Rezaei, Derakhshan, and Bagherkazemi (2011) said, critical thinking is students' ability to rationalize notions, problems, or cases. To achieve that objective, some experts recommended activities that involve questions to be asked by the students (Browne \& Keeley, 2001; Hughes, 2014; Rezaei et al., 2011).

The other skills of ${ }_{4} \mathrm{Cs}$ are communication and collaboration which are closely related to each other. In collaborative learning, students work together with others, so they need to discuss and communicate with their collaborative friends. That is why, communication is considered power to develop the success of human relations. If students have good communication skill, they can make good relationship with others. When it happens, they then can successfully achieve a learning goal that they share and learn from each other (Loes \& Pascarella, 2017). Additionally, in a context of second language learning, collaboration and communication can give students more space to practice the language which contribute to their new language development (Zwiers \& Soto, 2017).

From the teachers' side, as an attempt to enhance students' four skills, they could prefer classroom activities that stimulate students' creativity, critical thinking, collaboration, and communication. Bell (2010) suggested projects that students can do collaboratively involving brainstorming and generating idea as an alternative. Murtiningsih and Hapsari (2018) recommended some reading and writing activities to cultivate students' collaboration and critical thinking. Murtiningsih (2016) also introduced group painting followed by story writing based on the painting as a classroom activity that developed students' creativity, collaboration, and communication. Last but not least, Aldabbus (2018) suggested activities integrated with students' psychomotor and social skills such as finding information with different resources, increasing critical thinking, problem-solving, selfevaluation, summarizing also giving presentations to facilitate students' ${ }_{4} \mathrm{Cs}$.

\section{Research Methodology}

This qualitative research aims to investigate the implementation of $\mathrm{PbL}$ to develop the 21st century learning skills comprising creativity, critical thinking, collaboration, and communication. In regard to the aim which focused on understanding individuals' views and perceptions, this research stands under qualitative research and specifically belongs to 
descriptive qualitative. Creswell and Creswell (2018) mentioned that qualitative research is a research methodology that explores the meaning of individual groups and describes the social and human problems. Specifically, considering the aim which focused on a case that happened in a specific context, this research used a design of a case study in which Creswell (2012) stated this type of design is suitable to explore and get in-depth data since this research presents the finding by describing in detail through the phenomenon based on participants' viewpoints.

In terms of setting of place, this research was conducted in an English training program in Indonesia named Lantern School of English Education (LSEE). This program was chosen because based on the result of preliminary observation carried out by the researcher, $\mathrm{PbL}$ was widely implemented in classes offered by the program. On top of that, the program intends to equip the pre-service English teachers with the 21st century learning skills so that the pre-service English teachers could be an effective and professional English teachers after graduating from the program.

Multiple sources of data were employed to answer the research questions. In order to provide information of how PbL is implemented in LSEE, classroom observations in three different six semester classes were conducted and syllabus used in those classes were collected. PETs' final projects were also employed as data triangulation. Meanwhile, data to answer the second research question which is to understand how the implementation of $\mathrm{PbL}$ developed PETs' 21st century learning, in-depth interview to six senior pre-service English teachers of the program (sixth semester students) was used as the main data and triangulated by PETs' reflective essays that they submitted after they finished doing the final project.

The main data were collected through in-depth interview and observation while supplementary data were taken from documentation consisting of syllabus and final projects that the participants worked in three classes where the observation was conducted. The interviews were done to six senior PETs of the program (sixth semester students). The participants were chosen based on recommendation from a teacher who taught classes in which the researcher did preliminary observation. A set of criteria given to the teacher to help her sort the students were active in joining classroom activities, articulate in communication, elaborative in giving answers, and fulfilling the required percentage of presence in one semester. The six participants consisting one male (Carnation) and five female PETs (Azalea, Bougainville, Dandelion, Euphorbia, and Fuschia) were presented using a pseudonymous name in order to keep their real identity for research ethic.

After finishing the interview, the obtained data were analysed through transcribing, member checking, and coding. The interview data were transcribed and returned to the participants to be member checked which aimed to check the accuracy and resonance data results with participants experience (Birt, Scott, \& Campbell, 2016). Two participants asked the researcher to change the data. Azalea said that she wanted to delete one statement because the statement was unclear. Fuschia said that she wanted to change the statement because she realized she gave the wrong answer. After being revised and agreed by the participants, the data were coded using procedures suggested by Cohen, Manion, and Marisson (2011). As the first step open coding was done in which the researcher underlined words and highlight the words with a conspicuous color. Then the data were coded 
analytically by labelling the participants with a code as $\mathrm{P}_{1}, \mathrm{P}_{2}, \mathrm{P}_{3}, \mathrm{P}_{4}, \mathrm{P}_{5}$, and $\mathrm{P} 6$. That process was continued with axial and selective coding in which the categories were identifie and analyzed.

\section{Findings And Discussion}

The data revealed the implementation of PbL in LSEE was obviously seen from assessment, classroom activities, teacher roles, and student roles. All the participants agreed that those items could assist their creativity, critical thinking, collaboration, and communication.

\subsection{Assessment}

One of PbL manifestations in LSEE is through types of assessment given by the PETs. The syllabus showed that the assessment was usually conducted three or five times after all topics of materials had finished being discussed. In addition, the assessments were arranged in a form of final project related to the topic. From the PETs' work, most of the final projects were presented in a form of academic paper but one of them was an English textbook.

Through the interview, how PETs did the project was identified. In writing an academic paper, Fuchsia considered finding an idea as a challenging step. "We should find a case in our daily life and relate it to the concepts we learned," she completed the information. Dandelion said that in writing a paper, the students should organize the idea neatly. Dealing with textbook creation, Azalea said, "'we could not just copy from existing books. We had to create ourselves". Dandelion and Carnation perceived that the project taught them how to collaborate with other PETs. They shared the same learning objective and discussed how to achieve it. Dandelion stated, "we had to communicate a lot to make it work". Echoing to Dandelion's statement, Carnation told, "we share a lot of things such as content of the book, objective of the lesson we delivered through the book, and even the design. We decide all those things together."

Assessment that was carried out reflect PbL characteristics. First, it is shown through projects that the PETs had to do. In doing the projects, students are required to focus more on process rather than on the result. It is proved from all process that the PETs went through starting from formulating a learning outcome, understanding the concept of teaching material, training needed skills, designing the project theme, making the project proposal, and delivering the project works through any presentation of product. According to Jalinus, Nabawi and Mardin (2017), those processes are part of PbL implementation. The project also demanded them to interconnect the new concept they learned to their existing knowledge demo. In this situation, the main characteristic of PbL which students received new information without omitting what they have known previously (Kokotsaki, Menzies \& Wiggins, 2016).

In regard to the 21st century skills, as seen from the findings that the implementation of $\mathrm{PbL}$ could be impactful to PETs' creativity, collaboration, and critical thinking. That is supported by several experts, PbL is beneficial to students' development on those skills (Mali, 2016; Talat \& Chaudhry, 2014). In terms of creativity, ideas for final projects should be originally from them. They are not allowed to duplicate from other works. Isaksen, Dorval and Treffinger (2011) highlighted, innovation is part of creativity by explaining that creative individuals usually think beyond what other people think to find an innovative idea. 
Regarding collaboration, the PETs should accomplish the project in group. They had to discuss all components that they were going to use for the project which trained their collaboration and communication. According to Loes and Pascarella (2017), to work collaboratively, students need good communication skill. Through effective discussion, they could make decision then they could reach their learning objective or in this case, it is seen from the project accomplishment. In relation to critical thinking, projects can assist students to build that skill. Since they had to relate the concept their learned to their real life, it needs high order of thinking as said by Anderson and Krathwohl (2001). Additionally, in paper writing, they had to make their explanation logic and acceptable which Rezaei, Derakhshan, and Bagherkazemi, (2011)considered as critical thinking. PETs' collaboration and communication were also cultivated since some projects were done in group in which before making decision in doing all procedure of the projects, they had to discuss, compromise, and negotiate before executing the ideas. Working with peers to encourage PETs' communication and collaboration skill is also ever applied by Murtiningsih (2016) in an English classroom. When they could successfully communicate with others, their relationship to their groupmates will be warm and solid which affect to the project quality and conducive environment to learning.

\subsection{Classroom Activities}

To bridge PETs' understanding on materials, several types of activities are applied in classrooms. The data from syllabus confirmed by observation field notes showed two typical classroom activities that embedded PbL characteristics which were presentation and group discussion. Both activities required the PETs to work in group of four or five. The observation data also revealed, in presentation, each group was given an assigned chapter to read and share the materials on the chapter to classmates. Meanwhile, the discussion was done in two ways, group discussion and classroom discussion. Group discussion was done in group of three or four students each group whereas classroom discussion involved whole members of the class talking about the same topic and was led by the teacher. The two types of discussions aimed to help the PETs understand basic concepts that contributed to their final project accomplishment. The discussion was commenced by giving the PETs a case to analyze, a problem to sole, and a concept to be related to what was happening in real life.

In the interview, the participants perceived that classroom activities employed in LSEE could enhance 21st century learning skills. Bougainville said, before the presentation, they did some preparation. They met and discussed the material to gain mutual understanding and distribute parts that each member should present. After they presented the material to their classmates, they invited them to give questions or comments towards the content of the presentation. Bougainville uttered this activity trained her critical thinking and ability to work in group.

We need to give a logical answer to our friends' questions using understandable language. We also deliberated to decide who of us answer which question from the audiences.

In parallel, Carnation, Fuchsia and Azalea considered group discussion presentation in all classes they enrolled contributed to their communication skill. In details, Carnation said before the group made slides for presentation, all members should agree to what they were going to deliver. To reach the agreement, they discussed a lot of things in regard to the 
materials. "If we did not agree about a thing, we had to tell other members in a good way, trying not to offend anyone in the group," he uttered.

From the findings, it could be known that dominantly, classroom activities involved discussion and oral presentation. Setting up those activities which involved students' existing knowledge to digest new information from sources is one way to apply $\mathrm{PbL}$ in classrooms (Tsybulsky et al., 2020). In line with that, Kokotsaki et al (2016) mentioned a procedure to go through in $\mathrm{PbL}$ such discussion and exploration to respond the problem. Discussion that the students did enhance their communication skill as part of the 21st century learning skill. Moreover, because some activities are set in group mode in which the students have the same objective of learning, the implementation of PbL could improve students' collaboration. That is in line with Wongdaeng and Hajihama (2018) who scientifically proved that $\mathrm{PbL}$ positively affects collaboration and communication.

The use of discussion and oral presentation in $\mathrm{PbL}$ is also suggested by Bell (2010) who mentioned, in $\mathrm{PbL}$, students need to brainstorm and generate ideas before going further on their project. Since sharing and discussion encourages students to find a problem or to analyze a case, the activities are surely able to push students' critical thinking. Additionally, in some discussion, the teachers asked the students to make connection between the new lesson to what they have already known, they need to analyze and synthesize. According to Bloom's Taxonomy in Anderson and Krathwohl (2001), anlyzing, synthesizing, and evaluating belong to high order of thinking so that when student show that those ability they are able to think critically. Moreover, the students considered that they did discussion and presentation in most of subjects offered by the program. Nevid and McClelland (2013) mentioned, exposing the students to activities that support their critical thinking from time to time is an effective way to sharpen that ability. It can be predicted when it goes on, the PETs graduate from the program and get a job as an in-service teacher, they will present themselves with a good quality of critical thinking.

\subsection{Teacher Role}

The other aspect of instruction that reflects the implementation of PbL in LSEE is teacher role. Known from the field notes of observation, teachers played a role as a facilitator for the PETs. They provided reading materials for all topics, gave a case or a problem to discuss, and distributed a list of questions to lead discussion. In addition, the syllabus showed how the teachers facilitated the PETs learning which were by helping the PETs overcome difficulties in understanding materials or doing final projects through series of consultation. According to Fuchia, the consultation sessions helped her understand concepts and ensure that what she did for the project was on the track.

Additionally, in the interview, Euphorbia mentioned some roles played by the teachers in $\mathrm{PbL}$ classrooms which were organizing classroom activities to scaffold the students doing more challenging tasks, gave feedbacks on students' speaking and writing assignments, and assessing student' performance.

At the beginning of the semester, all teachers explained a course syllabus. They usually explained what we had to do in each assessment. They let us ask questions if we need more information ... Information in this syllabus was about aims of the courses, assignments, assessment, grading scheme, and classroom regulation. 
Dealing with the assessment, according to Azalea, the teachers usually gave rigid explanation about procedures and things that the PETs had to prepare. After that, they allowed the students to decide how they did the work and how the product they produced would be like as long as they did the project on the right track in order to achieve the learning goal.

In terms of the benefits of 21st century skills, in the interview, Fuchsia told that the teachers gave the students intriguing questions or problematic cases that they had to discuss with groups which, she thought, stimulated PETs' critical thinking. After that, the teacher wrapped up the discussion using digestible language and easy word choice that made her understand the material more. Focusing on the classroom activities, Carnation said that in group presentation, the teachers helped the presenters answer questions and explained the material further when the presenters got stuck in elaborating the answer. Another teacher role was stated by Bougainville, "before presentation, the teacher offered us consultation if we had problems in understanding the materials."

All things that the teachers did, based on what the PETs shared reflect the manifestation of $\mathrm{PbL}$. The teachers facilitated the PETs' learning starting from the preparation, implementation, and evaluation. In the implementation, the teachers monitored how the PETs did the process. What the teachers did as described by the participants represents constructivist approach which is the basic concept of PbL (Krajcik \& Blumenfeld, 2006). That notion is supported by Ertmer and Simons (2006) by saying that the suggested role that the teachers should play is being a facilitator in which the teachers need to assist the PETs when they need help. In order to make the PETs not hesitant to ask for help when they need it, the teachers are required to create a good student-teacher relationship which $\mathrm{Yu}$, Johnson, Deutsch, and Varga (2018) considered as an instrument for students' success.

Teacher roles give strong contribution to students' 21st century learning skills. As seen in the findings, the teachers gave PETs sufficient area to put their idealism and voices in doing the tasks. It indicated the teachers trusted the students' ability to finish the project. Hertzog (2007) emphasized the impact of the teachers' positive beliefs to students' potential to their ability in doing tasks that involve critical thinking skill. For instance, in relation to teachers' role in $\mathrm{PbL}$ which is giving questions or problems to lead the steps of $\mathrm{PbL}$, when the teachers trust the PETs' ability to answer problematic questions, they then will give an opportunity for the s PETs to show their critical thinking skill.

The finding also presented that teachers playing a role as a facilitator for the PETs is fruitful to enhance PETs' creativity. By providing students spacious room for their voices in the project, the teachers stimulated students' creativity. Differently, if everything is decided by the teachers, the PETs will not be freely able to put their idea and thought on the project and it hampered their creativity. Setting up group activities for the PETs could also be counted as the teachers' attempt to accommodate PETs' collaboration and communication development. The teachers also took part in enhancing PETs' critical thinking by giving them a list of questions and cases to be talked about with their group.

\subsection{Student Role}

The last variable that reflects the PbL implementation in LSEE is how the PETs take part in doing the project or in classroom activities. From the observation it is known that the PETs 
played an active role in the learning process while joining LSEE. It is in line with interview result in which all participants agreed to say that they participated actively in every activity that the teachers assigned. In details, Azalea said, "we read the materials prior, discussed with friends, and asked the teachers' help sometimes to figure out the topic." Adding the information, Dandelion uttered, "we presented the materials to our friends. Beforehand, we read the assigned chapter several times". Detailed information about students' active roles in the process of learning is explicitly explained by Euphorbia.

"One of classes that I enrolled, in semester three, I think, we had a project to observe how an individual learned a language. We came up with a question to lead the process. After getting data from the observation, we analysed the result to answer the question and wrote the report."

How their role as an active doer benefited their 21st century skills is shown from the interview data. Carnation perceived that all activities and projects made him more responsible and confident in making decision. Dandelion said, doing final projects, both textbook creation and paper writing, somehow enabled him to think systematically. For Bougainville, group works built her confidence. She uttered, "I become more confident in sharing my ideas to other people." Meanwhile, Euphorbia thought that the teachers encouraged all members of the group to participate in doing all activities and projects. "Since the teacher would not give us a score if we did not give contribution to the group work, I then participated in my group by doing my part well."

As presented in findings, students revealed their role in learning and how the role gives them rich benefits. They played a significant role as an active learner and it meets one of characteristics of PbL (Bedir, 2019; Tracey \& Morrow, 2012). In terms of 21st century skills that the students gained from the role, communication and collaboration are mentioned by the participants. Being more confident in stating mind and expressing ideas demonstrated students' improvement on communication skill (Ting, Marzuki, Chuah, Misieng \& Jerome, 2017). Their ability in doing collaborative works is also seen from their responsibility and involvement in group work. In parallel, Patel, Pettitt, and Wilson (2012) stated, responsibility is a fundamental characteristic that human should own to work collaboratively.

\section{Conclusion And Recommendation}

From the elaboration above, it can be concluded that the implementation of PbL can be integrated in any element of instruction. Each of them could be designated to support students' or PETs' 21st century skills comprising creativity, critical thinking, collaboration, and communication. Strategies chosen by LSEE to implement the approach deal with assessment, classroom activities, teacher roles, and student roles. All variables are related to each other. How the PETs achieve the main goal of learning is assessed through a quality project. The ultimate goal that each class set up is divided into some terminal objectives. Classroom activities are employed to monitor students' progress in achieving the sub-goals. PETs as an active learner facilitated by teachers' presence who are ready to assist their learning are strongly able to enhance their creativity, critical thinking. Since some projects and activities are carried out in groups, collaboration and communication are also increased. Thus, it is known, based on the participants' viewpoints, how LSEE implemented PbL is able 
to prepare their students to be a professional teacher with the 21st century skill qualification.

Information presented in this current research have recommendations to some parties. First, the research recommends other teacher training programs to implement $\mathrm{PbL}$ to produce creative teachers who are able to think critically, communicate effectively, and work collaboratively. Second, the recommendation is addressed to teachers who intend to apply PbL. They can get some views on variables of classroom instruction that can be integrated with $\mathrm{PbL}$ characteristics. Last, other researchers who are interested in studies on $\mathrm{PbL}$ and 21st century skills are suggested to fill the gaps of this research. Realizing that the data were taken qualitatively in a small context, the findings might not be representative to depict situation in different contexts. Thus, a study under the same topic involving more participants and a larger research setting is strongly recommended. On top of all that, to strengthen and justify the findings of this research and to complete results shown by a number of previous studies focusing on this area, quantitative studies that measure the effectiveness of PbL in developing EFL pre-service teachers' ${ }_{4} \mathrm{Cs}$ is also encouraged.

\section{References}

Aldabbus, S. (2018). Project-based learning: Implementation \& challenges. International Journal of Education, Learning and Development, 6(3), 71-79. www.eajournals.org

Allison, J. M. (2018). Project based learning to promote 21st century skills: An action research study. https://doi.org/10.25774/w4-m5xm-wc95

Almeida, L. da S., \& Wechsler, S. M. (2015). Excelência profissional: A convergência necessária de variáveis psicológicas. Estudos de Psicologia (Campinas), 32(4), 767-776. https://doi.org/10.1590/0103-166X2015000400019

Anderson, L. W., Krathwohl, D. R., Airasian, P. W., Cruikshank, K. A., Mayer, R. E., Pintrich, P. R., Raths, J., \& Wittrock, M. C. (2001). Taxonomy for assessing a revision of Bloom's taxonomy of educational objectives. Longman. https://www.uky.edu/ rsand1/china2018/texts/Anderson-Krathwohl - A taxonomy for learning teaching and assessing.pdf

Bani-Hamad, A. M. H., \& Abdullah, A. H. (2019). Developing female students' learning and innovation skills (4CS) in physics through Problem-based learning. International Journal of Academic Research in Business and Social Sciences, 9(12), 501-513. https://doi.org/10.6007/IJARBSS/v9-i12/6750

Bedir, H. (2019). Pre-service ELT teachers' beliefs and perceptions on 21st century learning and innovation skills (4Cs). Journal of Language and Linguistic Studies, 15(1), 231-246. https://doi.org/10.17263/jlls.547718

Bell, S. (2010). Project-based learning for the 21st century: Skills for the future. The Clearing House: A Journal of Educational Strategies, Issues and Ideas, 83(2), 39-43. https://doi.org/10.1080/00098650903505415

Birt, L., Scott, S., Cavers, D., Campbell, C., \& Walter, F. (2016). Member checking: A tool to enhance trustworthiness or merely a nod to validation? Qualitative Health Research, 26(13), 1802-1811. https://doi.org/10.1177/1049732316654870

Browne, M. N., \& Keeley, S. M. (2001). Asking the right questions: A guide to critical thinking. Prentice Hall. 
Cocco, S. (2016). Student leadership development: The contribution of project-based learning. Royal Roads University.

Cohen, L., Manion, L, \& Morrison, K. (2011). Qualitative research data gathering technique: Interview. In Research methods in education (7th ed., p. 758). Routledge.

Cresswell, J. W. (2012). An introduction to education research. In Educational research: Planning conducting, and evaluating quantitative and qualitative research (Pearson, pp. 2-28). Pearson.

Creswell, J. W., \& Creswell, J. D. (2018). Research design: Qualitative, quantitative, and mixed method (5th ed.). SAGE.

Ertmer, P. A., \& Simons, K. D. (2006). Jumping the PBL implementation hurdle: Supporting the efforts of $\mathrm{K}-12$ teachers. Interdisciplinary Journal of Problem-Based Learning, 1(1), 1. https://doi.org/10.7771/1541-5015.1005

Hertzog, N. B. (2007). Transporting pedagogy: Implementing the project approach in two first-grade classrooms. Journal of Advanced Academics, 18(4), 530-564. https://doi.org/10.4219/jaa-2007-559

Hughes, J. (2014). Critical thinking in the language classroom. Eli Press.

Isaksen, S. G., Dorval, K. B., \& Treffinger, D. J. (2011). Creative approaches to problem solving: A framework for innovation and change (3rd ed.). Sage Publications, Inc.

Jalinus, N., Nabawi, A., \& Mardin, A. (2017). The seven steps of project-based learning model to enhance productive competences of vocational students. International Conference on Technology and Vocational Teachers (ICTVT 2017). https://www.atlantis-press.com/proceedings/ictvt-17/25884523

Kokotsaki, D., Menzies, V., \& Wiggins, A. (2016). Project-based learning: A review of the literature. Improving Schools, 19(3), 267-277. https://doi.org/10.1177/1365480216659733

Krajcik, J. S., \& Blumenfeld, P. C. (2006). Project-based learning. https://free.openeclass.org/modules/document/file.php/ENG155/Projects online/CHAPTER 19 PBL Kraichik.docx

Krentzman, A. R. (2013). Review of the application of positive psychology to substance use, addiction, and recovery research. Psychology of Addictive Behaviors, 27(1), 151-165. https://doi.org/10.1037/a0029897

Loes, C. N., \& Pascarella, E. T. (2017). Collaborative Learning and Critical Thinking: Testing the Link. Journal of Higher Education, 88(5), 726-753. https://doi.org/10.1080/00221546.2017.1291257

Mali, Y. C. G. (2016). Project-based learning in Indonesian EFL classrooms: from theory to practice. IJEE (Indonesian Journal of English Education), 3(1), 89-105. https://doi.org/10.15408/ijee.v3i1.2651

Murtiningsih, S. R. (2016). Collaborative writing in an EFL context. Journal of Foreign Languange Teaching and Learning, 1(1), 82-90. https://doi.org/10.18196/ftl.118

Murtiningsih, S. R. (2017). Moody teachers ruin my motivation: An EFL student's voice on effective EFL teachers. Journal of Foreign Languange Teaching and Learning, 2(1). https://doi.org/10.18196/ftl.2114

Murtiningsih, S. R., \& Hapsari, W. (2018). Teaching reading to encourage critical thinking and collaborative work. In A. Burns \& J. Siegel (Eds.), International Perspectives on Teaching the Four Skills in ELT (pp. 153-165). Palgrave Macmillan. https://doi.org/10.1007/978-3-319-63444-9_11 
Nakano, T. de C., \& Wechsler, S. M. (2018). Creativity and innovation: Skills for the 21st century. Estudos de Psicologia (Campinas), 35(3), 237-246. https://doi.org/10.1590/1982-02752018000300002

Nevid, J. S., \& McClelland, N. (2013). Using action verbs as learning outcomes: Applying Bloom's taxonomy in measuring instructional objectives in introductory psychology. Journal of Education and Training Studies, 1(2). https://doi.org/10.11114/jets.v1i2.94

Patel, H., Pettitt, M., \& Wilson, J. R. (2012). Factors of collaborative working: A framework for a collaboration model. In Applied Ergonomics (Vol. 43, Issue 1, pp. 1-26). https://doi.org/10.1016/j.aperg0.2011.04.009

Pfeiffer, S. I., \& Wechsler, S. M. (2013). Youth leadership: a proposal for identifying and developing creativity and giftedness. Estudos de Psicologia (Campinas), 30(2), 219229. https://doi.org/10.1590/s0103-166×2013000200008

Rezaei, S., ... A. D.-J. of L., \& 2011, undefined. (2011). Journal of Language Teaching and Research. Academypublication.Com. https://doi.org/10.4304/jltr.2.4.733-739

Saxena, S. (2014). How do you teach the 4 Cs to students (Part-1): Creativity and innovation? http://edtechreview.in/trends-insights/insights/914-how-do-you-teach-the-4Cs-tostudents-part-1-creativity-and

Talat, A., \& Chaudhry, H. F. (2014). The effect of PBL and 21st century skills on students' creativity and competitiveness in private schools. In The Lahore Journal of Business (Vol. 2, Issue 2). http://lahoreschoolofeconomics.edu.pk/businessjournals/V2issue2/05 Talat and Chaudhry FINAL.pdf

Ting, S. H., Marzuki, E., Chuah, K. M., Misieng, J., \& Jerome, C. (2017). Employers' views on the importance of english proficiency and communication skill for employability in Malaysia. Indonesian Journal of Applied Linguistics, 7(2), 315-327. https://doi.org/10.17509/ijal.v7i2.8132

Tracey, D. H., \& Morrow, L. M. (2012). Lenses on reading: An introduction to theories and models (3rd ed.). Guilford Publications.

Treffinger, D. J., \& Isaksen, S. G. (2005). Creative problem solving: The history, development, and implications for gifted education and talent development. Gifted Child Quarterly, 49(4), 342-353. https://doi.org/10.1177/001698620504900407

Tsybulsky, D., Gatenio-Kalush, M., Abu Ganem, M., \& Grobgeld, E. (2020). Experiences of preservice teachers exposed to project-based learning. European Journal of Teacher Education, 43(3), 368-383. https://doi.org/10.1080/02619768.2019.1711052

Wongdaeng, M., \& Hajihama, S. (2018). Perceptions of Project-based learning on promoting 21st century skills and learning motivation in a Thai EFL setting. JSEL, 13(2), 158-190. https://soo4.tci-thaijo.org/index.php/jsel/article/view/113931

Wurdinger, S., Haar, J., Hugg, R., \& Bezon, J. (2007). A qualitative study using project-based learning in a mainstream middle school. Journals.Sagepub.Com, 10(2), 150-161. https://doi.org/10.1177/1365480207078048

Yu, M. V. B., Johnson, H. E., Deutsch, N. L., \& Varga, S. M. (2018). "She calls me by my last name": Exploring adolescent perceptions of positive teacher-student relationships. Journal of Adolescent Research, 33(3), 332-362. https://doi.org/10.1177/0743558416684958

Zwiers, J., \& Soto, I. (2017). Conversational discourse in context. Corwin Press. 